\title{
Development of science-environmental movement relationships: The case of Russia
}

\author{
Oleg N. Yanitsky \\ Professor, Doctor of Philosophy, Chief Researcher, Federal Center of Theoretical and Applied Sociology of \\ the Russian Academy of Sciences. Address: 117218, Russia, Moscow, bld.5, 24/35, Krzhizhanovaskogo str.
}

\begin{abstract}
There is a paradoxical situation in the world: after the end of the WWII the science took leading position in all spheres of human activity but there was no any fundamental research on science-environmental movement relationships. Recently, Russian science in public life exists in two major forms. First in the form of manifestos like the Pugwash Manifesto in the year of 1955 (Butcher, 2005) which resulted in long-term numerous gatherings, discussions and appeals to world community and the second in the form of scientists-turned-civil activists who consciously left their positions in research institutes and entered an environmental and other social movements. The following text is based on the empirical study of the above relationships from the early 1900s till now in its widest sense (i.e. including charity, justice, peaceful and other forms of civil activism). The major forms of this activism were as follows: the writing the programs of alterative development of science, industry and agriculture; a work as the tutors of the students' nature protection movement; the participation in the work of the committees on civil rights and freedoms; the establishment of alternative units of experts and advisers for public hearings, etc. In the run of this long-term period the situation is turned upside down: those who were students have become the scientifically-sound leaders of complex interdisciplinary movements without boundaries who actively participate in global transnational projects with global stakeholders on equal ground. It gives me the grounds to speak on the emergence of a new format of science-social movement relationships. The author suggests a hypothesis that the researchers of current environmental movements are needed in an integrated socio-bio-technical paradigm of actor-subject matter development.
\end{abstract}

\section{Keywords}

alternative, environmental movement, globalization, civil activism, nature, paradigm, science, scientist-turned-activist, social movement, time

\section{On current relationships between scientific and experimental knowledge}

There is a paradoxical situation in the world: after the end of the WWII the science took a leading position in all spheres of human activity but there was no any social movement of scientists. There is a set of their distinctions which have to be taken into account. As history of science showed, a basic ground of any research had been a certain paradigm as generally accepted worldview (Khun, 1962). But for a long time the paradigmatic approach was mainly applicable in natural sciences dealt with physical world. But the more the world had become man-made and man-transforming, the more scholars have been forced to replace a static paradigmatic approach by more flexible one that is by a set of concepts which have replaced each other in time. Nowadays, the theorists of modern world inclined to describe it as unstable, with non-linear trajectory of development accompanied with permanent unintended consequences and twists.

Roughly speaking we have currently two types of knowledge. The former is produced in labs or/and as a result of the R\&D projects, while the latter is an experimental one produced by insiders or/and by observers of a particular developmental project. Or it's a result of permanent monitoring of implementation of such projects or of emerging of natural or man-made disasters. Therefore, the former is a conceptually-built knowledge while the latter is an emergent one. This distinction of two types of knowledge is resulted in an existence of two institutions of knowledge production: an academic community and civil society with its organizational structure, networks, codes of behavior, etc. Of course, this distinction is relative because in practice they are interrelated and moved fourth each other. But in some cases academic institutions are so highly dependent on political ones that they are losing the ties with current reality and its trajectories, be it of local, national or global scale. There are many other distinctions between the above two types of the knowledge production, i.e. between the scientific and the emergent ones.

\section{Theoretical and empirical basement}

The paper is based upon the Anglo-Saxon works on theoretical sociology (Seligman, 1992; Robertson, 1994; Beck, 1999, 2007; Castells, 1999; Urry, 2008; Sassen, 2000; Schwab, 2016). Then, it is based on the investigations of European sociologists of social movements ${ }^{\star \star \star}$ (Klandermans et al., 1988; Kriesi at al., 1995; Diani and McAdam, 2003; Della Porta and Diani, 2006). It relies upon the works of sociology of science (Irwin and Wynne, 1996; Irwin, 2001). Three lines of the above studies were the most important: the world's mobility, its non-linear (oscillating) development and network structure. As to the works of Russian scientists, it first of all was the works of V. Vernadsky $(1995,1995 a)$ and A. Chizhevsky (1924, 1976) who had developed the foundations of humanity and the Biosphere relationships. In the beginning of XX century there was a group of Russian pioneers and discoverers like I. Chersky, N. Przheval'sky and P. Semenov-Tyan-Shan'sky who made a full geographical picture of a huge Russian territory. Without their field and theoretical research and the works of their followers the emergence and shaping of environmental movement in Russia would be impossible. 
In the run of the last 50 years l'd studied an emergence and development of the Soviet and Russian environmental movement in the run of three international and several national research projects. The methods of my research were as follows: including observation, case studies, in-depth interviews not only with activists but with their adversaries and bystanders, secondary analysis, building the models of critical environmental events (disasters and man-made catastrophes), the study of human documents and, of course, desk researches. Besides, the method of critical secondary analysis has been used in relation to my previous works on the issue in question (Yanitsky, 1996, 2009; 2012; 2016). The archive of my interviews is accessible to all on the Official Site of the abovementioned Federal Center. In the following sections I present the results of my findings on science-civil activism relationships as a succession of steps developed in space and time but it doesn't mean that this succession has a linear character.

\section{Early 1900-1920s}

In those years there had been a set of interrelated group of environmentalists. The first one had been highly educated intellectuals who were in favor of protection of unique species and their habitats. They were the founders of the system of natural reserves in Russia. The second one was the pioneers and the pathfinders who began to study an immense space of Russia and contiguous territories systematically. It had been absolutely necessary activity without which it had been impossible to understand the structure and functions of various ecosystems. The third one like V. Vernadsky and $A$. Chizhevsky $(1926,1974)$ recognizing the importance of pioneering activity saw an environmental issue more globally that is through the lenses of the Biosphere concept and considered human behavior as dependent on fluctuations of solar activity. It's indicative for Russia that many of Russian intellectuals had been not only the scientists but political activists or/and political figures. The importance of environmental studies, natural and social, had been stimulated by the horrible consequences of the WWI (1914-16), the October revolution (1917) and then by civil war (1918-22) that embrace almost all territory of Russia. Nevertheless, the investigations of the giants of Russian science had mainly a desk-research character not directly tied with ongoing fundamental social transformations. But the models of ideal examples of human settlements had been urgently needed. That is why the E. Howard's idea of the 'Cities of Tomorrow' (1902) had been very popular before and after the October revolution. To my mind, a small human settlement with friendly environment is still very attractive image in Russia but nowadays it has become a privilege of the riches.

One thing has to be mentioned. In that period a 'paper town planning' has flourished that usually totally ignored a natural landscape. Such habit of designing of apartment houses, neighborhoods and towns appeared very resistant for years.

\section{0-30s: industrialization, collectivization and the discussion on a socialist city}

It had been clear that such radical transformations will change a total natural and social landscape of the country. The main pressure of millions of peasants-turned-industrial workers will be on large cities that had not been prepared to their influx. That is why it was decided to organize a scientific and public discussion on a future of a socialist city.

It was a unique case because in the run of discussion during the 1928-31s in it took part many leading political figures like N. Krupskaya, L. Krzhizhanovsky, A. Lunacharsky and other officials as well as academics, architects, students and various ad hoc groups. La Corbusier, A. May and other foreign architects and city planners took part as well. Unique one, because it had been the only one case of such vide and democratic event. In the run of discussion two adversarial parts had emerged, the urbanists and des-urbanists. Besides, the discussion gave rise and publicity for the architects-turnedsociologists to offer variants of so called of houses of collective way of life (literally, doma novogo byta). As it usually happened in those times, the Communist party leaders quickly ended the discussion and adopted a master plan of Moscow as a model for future social and urban planning. Nevertheless, some ideas of urbanists and des-urbanists had been realized in master plans of such new industrial cities as Magnitogorsk and Stalingrad (Kotkin, 1991). As to 'ecological question,' it's indicative that the term a 'green city' which had emerged in the run of discussion is in use among sociologists and urban planners up to now. The science as such had mainly been excluded from the discussion's context. Its participants appealed directly to political ideas.

\section{0-60s: post WWII rehabilitation, N. Khrushchev Thaw}

It had been the worst decade for Russian scientists-turned-civil activists. Though a political opportunity structure of the abovementioned discussion on the Socialist City had been democratic, the actual environmental policy debates took place behind the public arena. Once again the communist ideology took over an advance science. The Stalin's Plan of Nature Transformation was adopted in the 1948 by his personal initiative. It should be mentioned that this Plan had been developed by a group of the Soviet outstanding scientists. Its key idea was the construction of a set of protective forest belts, mainly in the European South-East of the country. But at the same time it had been the time of cruel persecution on the backers of the Weismannist-Morghanists' worldview and on the genetics. So-called people's academician T.D. Lysenko organized a persecution of genuine scientists. All-Russian society for Nature Protection still existed but it was one of driving belts of the Communist Party among many others. Nevertheless, as D. Weiner showed (Weiner, 1999) the scientists-turned-civil activists alone and their small organizations like the Moscow Society of Naturalists continued their struggle for nature protection. But it's interesting that in the 1960s the generation of future eco-activists were the students at Soviet universities. To my mind, we, Russian sociologists and politicians, are underestimating the role of a person in the history of science-public relations and in construction of discursive mode of their communication. And the reserves served as a testing ground for it. It's indicative that mega-cities and especially Moscow had been under strict control of the CPSU. All natural areas within and outside the capital were strictly protected. 


\section{The 1970s -- the 1980s}

It had been a critical period of the emergence and rapid development of Russian environmental movement. A couple of domestic and international events gave a cumulative effect. First, it is going on the emergence of the students' nature protection movement initially under supervision of the university academics. From its very beginning, this movement had been network-structured. In Siberia the movement of adults from various social strata had emerged. Second, it was the years of the development of basic environmental laws on the protection of nature of the country, on strictly protected natural territories, on ecological expertise, the project of the Laws on Ecological Safety, of the Federal Natural Resources and some others. An environmental policy was rapidly institutionalized. Thirdly, it had been the years of intensive collaboration of Soviet/Russian scientists and scholars in the UNESCO's programs on Ecological Year and the Man and the Biosphere. Fourthly, the late 1980s were the years of the emergence of grassroots activism initially named as the 'movement of informals' (neformaly) that is various civic initiatives aimed at protection of natural and cultural monuments. Fifthly, this variety of initiatives, protest actions and movements meant the emergence of civil society, top-down and bottom-up network organized, and their computerization gave them and additional strength. Sixthly, a humanitarian intelligentsia (writers, journalists, architects, cinematographers) actively participated in the above processes and structures. Seventhly, simultaneously the local lore movement overcoming its ethnographic character acquired a new breath. Eighthly, the centers of technical creativity initially established by the Yong Communist League have been gradually transformed into ecological NGOs. Ninthly, of course this raise had not been free from 'fellow-travelers.' Tenthly, the abbreviated vitas of some Russian environmental activists the reader can find in my Environmental archive.

Some of my western colleagues stated that the above transformations would be impossible without western financial aid and professional assistance. It's the wrong statement. No one western theorist predicts the decay of the Soviet Union. They didn't take into account some basic transformations in Soviet society, namely that it had become well-educated and informed on what was going on in the West. Leading Russian environmentalists worked in the UN, the UNESCO and other international organizations. And in those times my Western colleagues had no access to the information related to current public moods, especially in remote provinces. It should be mentioned that in 1992 the leaders of the New Independent States including B. Eltsyn adopted a draft of the Inter-State Ecological Agreement (developed by A. Yablokov) related to the principles of their collaboration in an environmental field. Unfortunately, the majority of these states never remembered about this project.

\section{The 1990s}

The beginning of the period was marked not only by the rise of environmental movement but by the establishment of a variety of its political composition ranging from conservationists (traditionalists) via socialists and till left-wing alternativists and anarchists. The 'right' wing was composed mainly of adult people while the 'left' one - by the young ones (Yanitsky, 1996). Accordingly they differed in the forms of activism. The former practiced dialog and other peaceful forms whereas the latter preferred direct actions. Being a participant of long-term research project on New Social Movements in Russia guided by Alain Touraine, I had an opportunity to observe the process of rapprochement of the leader of the above wings. The method of sociological intervention developed by Touraine and his colleagues allowed me to see the details of this rapprochement.

Nevertheless, in the scale of the country there had been no such rapprochement for several reasons. First, the coming of democracy regime allowed to local activists to discover many urgent environmental issues of local and regional scale. Second, an ecological stance of some of them opened them an opportunity to become politicians or businessmen. Of course, the international programs like the 'Taiga Rescue' assisted in a manner for joining efforts of environmentalists. But business blocked all their initiatives. Third, three largest environmental organizations, the WWF, the Greenpeace and the SEU International had their headquarters in Moscow that makes their image as 'capital organizations.' Fourth, already existed political party 'Yabloko' has very strong environmental wing competing with the SEU International and other large Russian environmental organizations. Fifth, as my investigations showed, local grassroots were very dependent on local administration, on the one hand, and had no close ties with the biggest environmental NGOs, on the other hand. It's rather indicative that 'Yabloko' members permanently present at public debates organized by the central TV of the RF and local activists not. Finally, local and regional administration conducts the politics defined by the interests of the RF government and Big business.

\section{The early 2000s}

A couple of value, institutional, organizational and personal factors slowed down the development of Russian EM. First, it had been a radical change of national agenda. The aims and values such as capital accumulation, consumerism and personal carrier came to the forefront. Accordingly, the ecological legislation and interrelated laws and norms had been gradually changed. Second, it's impossibility to institutionalize the EM. Formally, the RF constitution contains the articles of human rights and freedoms. But actually these principles had been restricted by numerous norms and instructions issued by city or local administrations in every particular case. Besides, a lot of a 'parallel' or counter-movements had been established. The state and big business created a lot of NGOs under their control (state, regional and local chambers, consultative committees, etc.). Third, the resource-oriented state and business politics came in contradiction with the aims and ultimate goals of the EM. As a result, some of environmental laws (for example, the Forestry codecs) had been adapted to the business interests. Step by step, the majority of the achievements of the 1980s had been dismantled. For example, the public hearings turned in a formal and power controlled sittings. In every particular case the independent scientific experts may be replaced or opposed by politically-engaged ones.

2514 | P a g e

January 2018 
Fourthly, the media took the leading position in shaping of stereotypes of ecological thinking and activity of rank-and-file people. The entrance of eco-activists at central TV had been strictly forbidden. These people had accustomed not to participate in a particular environmental action but to listen the radio or see the TV-pictures of environmental 'hot-spots' (accidents, disasters, etc.). Fifthly, such time-and-resources restricted events as the 'Year of Ecology 2017' had been perceived by people as one more arrangement but not as an appeal to return to environmentally-sound politics.

Sixthly, the changes in a 'human material' of the EM deserve special attention. To my mind, a weakening of the EM of that time had been a result of the exhausting of social resource of its pioneers. Their aging, lack of financial and other resources, family obligations and uncertain personal prospects, all this taken together led to such exhausting of ecoactivists. It doesn't mean that the EM activists stopped their activity. It means that it took another, more traditional forms like the Enlightenment and education of schoolchildren and students or administering of legal ecoNGOs such as the WWF or Greenpeace Russia.

Seventhly, by and large it has become clear that environmental politics it is not a set of legal acts but an uninterrupted process, endless dispute and permanent change of distribution of forces. The matter is that a science is not fit to this mobile and permanently transforming process. Modern sciences, natural and social, are still much more oriented to study a structural-functional organization of world community than to comprehend it as complex and mobile socio-bio-technical entity.

Eighthly, recently emerging conflict between a set of the US cities including New York with the largest world oil corporations is rather indicative because it shows that these corporations are guilty in climatic changed led to sharp raise the taxes on heating, street cleaning and other urban services (http://www.interfax.ru/world/594917)

\section{0s years}

Nowadays, Russian environmentalists began to realize that any environmental issue is always multi-level, local, regional and global, and these levels are interconnected. All-embracing character of such issues led to the leveling of political differentiation between groups of Russian environmentalists, mentioned earlier. Their common goal is a nature protection politics. In my early article (Yanitsky, 2012) I wrote about their 'political turn.' Now l've to clarify: the politics for Russian environmentalists meant not the participation in the struggle of political parties but the politics of maximum nature protection at all levels. More than that, they try to maintain their activity at international level participating in some crossnational projects like the New Silky Road and protection of ecological sustainability of Arctic environment.

There are two interrelated shifts. On the one hand, the Internet is overloaded by scientific and empirical information. Therefore, civil activists have only to learn to use such data correctly. On the other hand, these well-educated and highlyexperienced activists have become professional politicians capable to gain necessary information and to use it in a right way. Anyhow, they knew much more than any political party members because the activists are much more concerned with social and environmental issues than political party members. As l've recognized earlier a key figure in any political decision is not party member but its assistants.

By and large, Russian environmentalists realize a necessity of the study of metabolic processes, both in the run of mannature interactions and a social metabolism as such as a result, for example, of mass emigration processes across the world. It had been a principled turn. It's indicative that earlier local grassroots had been focused on local cases of poisoning of nature or urban milieu. But after a set of natural and man-made disasters they realized that any local event may has regional or global consequences. The long-term existence of the Union of Chemical Safety of Russia gave the impetus to environmental activists to be more focused on metabolic processes. This Union has been a very important bridge between scientists and activists.

In contrast to the EU (see, for example, Haberl et al., 2016) an energy saving is not on the top of national political agenda in Russia. Following scientists, Russian environmentalists are first of all concerned with a violation of the Biosphere turnover and coming global warming generated by human interference into evolutionary formed natural processes and ecosystems. In other words, these environmentalists (in their own manner) follow the warnings made by Vernadsky and Chizevsky in the 1920s. Besides, the environmentalists are also concerned with the multiplication of critical zones that is the territories totally destroyed by conflicts and wars across the world.

The abovementioned urgent issues define the environmentalists-scientific community relationships. Besides, as it has been already said, many modern Russian environmentalists are already well scientifically-prepared. Once again: today there is no insuperable barrier between the production of scientific and empirical knowledge. As the key moment of environmental knowledge production is a decision-making at any phase of this process, a journalist's investigation has become very popular in Russia and worldwide. It reminds me the fact that in the 1920s some participants of human ecology creation in the US had initially been muckrakers.

It's rather interesting that the year 2017 had been officially announces in Russia as 'The Ecological Year.' But Russian scientists have neither time nor resources to launch any research projects of national scale. Our media interpreted the main aim of this Year as a 'cleaning' of territory, especially of large cities. Once again: any source of local pollution may have global negative consequences. It turns out not an easy task especially as concerns of various kinds of liquid and solid wastes as well as of pollution of cosmic space. Due to the thematic compartmentalization of scientific institutions there was no impetus to launch any interdisciplinary project. More than that, the situation turns upside down, the leaders of environmental initiatives (for example, the Group of Rivers without Borders) began simultaneously to use already existing

2515 | P a g e

January 2018

https://cirworld.com 
research findings and to construct their own models of the development of a particular inter-state project and methods of prediction of its environmental consequences.

All said above doesn't mean that Russian environmentalists have become apolitical. It only means that they struggle for nature protection has shifted from the streets into institutional structures like the State Duma (Russian parliament), its committees or towards official public organizations like central, regional or local Public Commons. After the death of such scientists-turned-activists as A. Yablokov, A. Fedorov, scholars as acad. L. Lichachev, and writers as F. Taurin and V. Rasputin there are no figures capable to bridge the gap between various branches of science and practice of environmental protection and cultural heritage (for details see, for example: Ekologicheskaya al'ternativa, 1990).

But nowadays, Russian environmentalists have to take into account a mainstream of economic politics of Russian stakeholders and the domination of mass media at the national arena. How to make them more human and environmentally-sound is an open question.

\section{Conclusion}

For the reason of a giant territory of Russia and neighboring spaces as well as for its permanent South-East development the mode of thinking of Russian pioneers and pathfinders was globally-oriented. Such kind of thinking was peculiar not only to field researchers but to Russian scholars as N. Danilevsky and writers as F. Dostoevsky, L. Tolstoy and A. Chekov. In spite of horrible social consequences of the communist regime the very idea of world's brotherhood coincided with the above mode of thinking. In his programs written in 1917, Vl. Vernadsky several times reminded that Russian politics underestimate a huge scale of Russian territory (Vernadsky, 1995, 1995a).

In early 1900 and afterword, Russian scientists initiated Russian environmental movement, firstly in the form of the reserves of natural and cultural heritage, then in the form of a green and other ideal cities, after then as grassroots and other civic initiatives and finally in the form of network structured environmental movement with multisided continental and global ties. Recently, to my mind, Russian environmental organizations following globalization process is quickly transforming into a developing international network structure that follows or sometimes outstrips an international developmental projects like the New Silky Road.

It means that now the above environmental networks have no territorial margins. Like the Rivers without the Borders they accompanied (convoyed) the developmental process. In turn, it means that such network organizations represent not a certain territory but a rather complex and permanently developing geopolitical process. A 'turn to politics' of Russian environmental movement about which I wrote earlier (Yanitsky, 2012) has now acquired a new sense. It's now a turn to geopolitics burdened with multisided economic and political turns and twists. Finally, it leads us to the conclusion that this shift urges scientists and scholars to think about movable and interdisciplinary science. That is, rapidly evolving practice is outstripping the development of science as an institution. Does it mean that movable civil organizations have become so experienced and scientifically matured that now they are able to compete with mighty transnationals? All said above means that environmental movement not only spatially expanding but transforming into science-civil activity tandem.

\section{Discussion}

If one looks on all said above more generally, he will see that fundamental transformations are going on. To my mind, we are at the turning point of the sciences-civil activism relationships because the existing models of their relationships are no more fit to global dynamics. First, the production of scientific knowledge, especially if we speak about an environmental one, is lags behind the pace and production of geopolitical transformations and decision-making. It's quite natural that the development of any scientific concept needs a lot of time and resources, then it have to be tested, corrected, timely implemented, etc. Recently, the theoretical thinking has permanently to outstrip a changing, i.e. of emergent reality.

Second, academic knowledge is usually less interdisciplinary than emergent one produced by social movements for several reasons. For example, the more disciplines are participated in scientific knowledge production the more difficult to reconcile them and to build a certain not inherently contradictory concept. Besides, the building of any scientific concept is a long-term process dependent on a lot of bureaucratic norms and requirements.

Third, our world is permanently speeding up while the majority of its concepts are still static. For example, there are a lot of globalization concepts but each of them is static in essence. If one takes the sociology as an example, he will see a variety of structural-functional concepts of global whole but quite a few examples of its dynamic nature. The knowledge produced by modern well-educated civil society agents is more mobile and diversified. Besides, since its agents are working in the frames of emergent paradigm an acquired knowledge is permanently enriched and modified in accordance with changing local-global geopolitical situation.

Fourth, taking the issue more generally, l'd say that the scientists are studying the most general laws and regularities while the grassroots and their backers from academic community are based on a presumption of permanent dynamic of macro and microsystems. Scientists tend to study sustainable structures and systems whereas the grassroots are forced to analyze permanently changing structures and networks, that is an uninterrupted dynamics of a system in the run of which it exerts an impact on environment and changes itself.

Fifthly, there are differences between the two types of knowledge production in their relationships to such factors as time and space. The scientists intend to reveal the regularities of their subject matters but within more or less stable space-time rhythms. For the grassroots as the insiders and interested actors the space-time factor means a development of a certain

2516 | P a g e

January 2018

https://cirworld.com 
project under an impact of variety of social and natural conditions. If one takes again an example of the New Silky Road developed by China he'll see that it cross the boundaries of many nation-states and capable to exert a huge influence on natural and built environment worldwide. It means that is going on about continuous or even endless conjugate actorenvironment dynamics.

Sixth, in any case the grassroots or the NGOs as the producers of an emergent knowledge are much more mobile than academics for many reasons: they are smaller, much less restricted by national and international laws and by artificiallyconstructed protocols and codes of behavior. It seems to me that we are witnessing the emergence of a certain permanently developing science-practice hybrid. Recent environmentalists are real hybrids of knowledge and civil activism. Let me remind that many times ago it had been noted that a researcher should follow the actor (see, for example, Fisher, 2003).

Seventh, is the knowledge produced by civil actors (with assistance of various independent experts) is more valid than that of produced by academics? To my mind, for large cross-disciplinary projects the answer will be 'yes' for many reasons. As it has been mentioned earlier, the knowledge gained by civil actors is mobile and more fits to a particular territory or region. Then, these actors are capable to mobilize the knowledge from diverse sources around the world and thus such knowledge will be more not only scientifically but socially-sound. After then, as a rule civil actors know a particular situation under consideration much better than academics. For civil activists there is no problem to address to a particular domestic expert or from abroad. l'd like to underscore once again that overwhelming majority of such activists are well educated and experiences persons who know a lot of means for gaining expert knowledge or to reach a consensus with business and local administration. Finally, in the case of a conflict such activists can appeal to the media and by means of them to dismantle a wrong decision.

Eighth, a socio-bio-technical metabolism is not yet sufficiently investigated. The scientists, scholars and IT-engineers are dealing with such metabolism every day. But the use of various statistics including Big Data for resolving these complex issues is insufficient. Partially, civil activists are permanently encountering with the facts of such metabolism but they have no instruments for analyzing such complex transformations. In their turn, the scientists permanently study metabolic processes using economic statistics (Haberl et al., 2016). But it's insufficient because the very mechanisms of short-term and long-term metabolic processes remain not discovered. It's surprising that archeologists and other scholars widely use a crowd-sourcing methods while the scientists are usually not. Thus, the existing division of labor between scientists and civil activists has become obsolescent.

Tenth, it seems to me that modern environmentalists are needed in a New Human Ecology Paradigm like that which had been developed by the Fathers of the Chicago School of Human Ecology about 100 years ago. This New Paradigm has to comprehend the most substantial features of information age such as its geopolitical essence and mobile, interdisciplinary and technologically-constructed character of any processes. This paradigm has to be developed and supported by environmental movement of scientists and scholars. 'Science has to work on nature and human well-being', this motto is much more acute than ever before.

Eleventh, I suggest a hypothesis that the New Paradigm has to reflect a complex, systemic character both of local-global transformations and the response of science-civil activism to them. That is we are needed in an integrated socio-biotechnical paradigm of actor-subject matter development. It means that an integrated movement of scientists and civil activists has to be capable to resolve such complex and mobile issues. All above principles are needed in interdisciplinary methodology and research instruments.

Twelve, I see the failure of already existing global social movements as temporary ones, mainly for their one-sided character and preemption of their goals by international charity and other organizations. Following the logic of the actorsubject matter development, this world science-practice social movement should be interdisciplinary one and guided by the transformations of global socio-bio-technical sphere. It means that this movement will be less spontaneous and much more socially-constructed. Finally, the modern Russian science-civil activism tandem has one more advantage. It much less infected by the production of fake news and by manipulation of public moods. In all cases in question one should distinguish such working tandems aimed at resolving particular environmental issues from an activity of politically-engaged experts.

\section{References}

1. Beck U. (1999). World Risk Society. Malden, MA: Polity Press.

2. Beck U. (2007). Cosmopolitan Version. Cambridge: Polity Press.

3. Butcher S.I. (2005). The Origins of the Russell-Einstein Manifesto. Available at: http://pugwashconferences.files.wordpress.com/2014/02/2005 history origins of manifesto3.pd

4. Castells M. (1996). The Information Age. Economy, Society and Culture. Oxford: Blackwell Publishers, Ltd.

5. Castells M. (2000). Materials for an Exploratory Theory of the Network Society. British Journal of Sociology, 51 (1). Jan/March: 5-24

6. Chizhevsky A.L. (1924). Fizicheskie faktoryistoricheskogo processa [Phisycal Factors of a Historical Process]. Kaluga: Pervaya Tipolitigraphiya. 
7. Chizhevsky A.L. (1976). Zemnoe eho solnechnykh bur' [The Earth Echo of Sun Storms]. Moskva: Mysl'.

8. Della Porta D. and M. Diani. (2006). Social Movements. 2nd.ed. Malden, Mass: Blackwell.

9. Diani M. and D. McAdam, eds. (2003). Social Movements and Networks. Relational Approach to Collective Action. Oxford: Oxford University Press.

10. Fisher F. (2003). Citizens, Experts, and the Environment. The Politics of Local Knowledge. Durham and London: Duke University Press.

11. Haberl H., Fisher-Kowalski M., Krausmann F. and Winiwater V., eds. (2016). Society-Nature Relations across Time and Space. ISBN (on-line): 978-3-319-33326-7. Available at:

12. http://link.springer.com/book/10.1007\%2F978-3-319-33326-7

13. Howard E. (1902). The Garden Cities of Tomorrow. London.

14. Irwin A. (2001). Sociology and Environment. A Critical Introduction to Society, Nature and Knowledge. Malden, MA: Polity.

15. Irwin A. and Wynne B., eds. (1996). Misunderstanding Science? The Public Reconstruction of Science and Technology. Cambridge: Cambridge University Press

16. Khun T. (1962). The Structure of Scientific Revolutions. Chicago: The Chicago University Press (First Ed.).

17. Klandermans B., Kriesi H., Tarrow S. (1988). From structure to action: comparing social movement research across cultures. London: JAI Press, Inc.

18. Kotkin St. (1991). Steeltown, USSR: Soviet Society in Gorbachev Era. California: University of California Press.

19. Kriesi H.P., Koopmans R., Dyuendak J. and Giugni M. (1995). New Social Movements in Western Europe. A Comparative Analysis. Minneapolis: Univ. of Minnesota Press.

20. Lemeshev M., ed. (1990). Ekologicheskaya Al'ternativa [An Ecological Alternative]. Moskwa: Progress.

21. Sassen S. (2000). Territory and Territoriality in the Global Economy, International Sociology, Vol. 15 (2): $372-393$.

22. Robertson R. (1994). Globalization. Social Theory and Global Culture. London: SAGE Publications.

23. Schwab K. (2016). The Fourth Industrial Revolution. Geneva: World Economic Forum.

24. Seligman A. (1992). The Idea of Civil Society. N.Y.: The Free Press.

25. Vernadsky V. (1995). Zadachi nauki v sviyazi s gosudarstvennoi politikoi Rossii [The aims of sciences in connection with the state policy in Russia], in: VI. Vernadsky. Publicistics / Volkov V.P. ed. Moscow: Nauka publishing House, pp. 240-241.

26. Vernadsky V. (1995a). Ob osnovakh agrarnoi politiki v Rossii [On the foundations of agrarian politics in Russia] in: VI. Vernadsky. Publicistics / Volkov V.P. ed. Moscow: Nauka publishing House, pp. 241-251.

27. Weiner D. (1999). A Little Corner of Freedom. Russian Nature Protection from Stalin to Gorbachev, Berkeley, Los Angeles, University of California Press.

28. Yanitsky O. (1996). The Ecological Movement in Post-Totalitarian Russia: Some Conceptual Issues, Society and Natural Resources, 9, pp. 65-76.

29. Yanitsky O. (2009). The Shift of Environmental Debates in Russia, Current Sociology 57 (6): 747-766.

30. Yanitsky, O. (2012). From Nature Protection to Politics: The Russian Environmental Movement 1960-2010. Environmental Politics. 21 (6): 922-940.

31. Yanitsky O. (2016). Sotsiobiotechnical systems: A new Approach to Man-Nature Interactions, in: On Globalization and its Environmental Consequences. The Yanitsky Reader II Available at: http://www.isras.ru/index.php?page id=1198\&id=4603 pp. 123-135. 17/01/2018 